\title{
CARRIER DETECTION IN JAPANESE HAEMOPHILIA A FAMILIES USING FACTOR VIII GENE PROBE (F8A) AND THE GENE-LINKED ST 14-1 PROBE
}

\author{
Masato Nishino, ${ }^{1}$ Takuya Nishimura, ${ }^{1}$ Hiroyuki NAKA, ${ }^{1}$ \\ Sadaaki Mikami, ${ }^{1}$ Takashi Tokıno, ${ }^{2}$ and \\ Tomoaki Murotsu ${ }^{2}$ \\ ${ }^{1}$ Department of Pediatrics, Nara Medical College, Kashihara, Nara \\ 634, Japan \\ ${ }^{2}$ Institute for Molecular and Cellular Biology, Osaka University, \\ Suita, Osaka 565, Japan
}

\begin{abstract}
Summary Carriers of haemophilia A were detected in 20 Japanese families with using the factor VIII gene probe (F8A) and the gene-linked ST 14-1 probe. Polymorphism by the use of the BclI and F8A probe detected the smaller allele $(0.9 \mathrm{~kb})$ in $86 \%$ and the larger allele $(1.2 \mathrm{~kb})$ in $14 \%$ of the 65 normal $X$ chromosomes. The frequency of $B c l$ polymorphism was $30 \%$ in 30 normal females. In six out of 20 haemophilia $\mathrm{A}$ families, the haemophilia gene was identified by $B c l$ I allele polymorphism. The use of TaqI and the ST 14-1 probe detected 11 carriers in 20 haemophilia A families. In 14 families ( $70 \%$ ), either the $B c /$ I polymorphism in the factor VIII locus or TaqI polymorphisms in the ST 14 locus was useful for carrier detection.
\end{abstract}

\section{INTRODUCTION}

Haemophilia $\mathrm{A}$ is an $\mathrm{X}$-linked recessive bleeding disorder caused by the deficiency of plasma factor VIII coagulant activity affecting approximately 1 in 10,000 males. Although replacement therapy for haemophilia $A$ has been reasonably satisfactory, the disease puts a considerable strain on families. Therefore, advances in carrier detection and prenatal diagnosis are required to determine the risk of haemophilia A. So far, carrier detection techniques have depended upon the biological activity and immunological analysis of factor VIII and have been only 70 90\% accurate (Graham et al., 1986; Green et al., 1986).

The locus for the factor VIII protein has been assigned to the long arm of the human X-chromosome at Xq28qter (Drayna et al., 1984; Tantrabahi et al., 1986). 
The complementary DNA (cDNA) structure for human factor VIII has been clarified (Gitschier et al., 1984) and several intra- and extragenic factor VIII DNA probes have been developed for carrier detection and prenatal diagnosis (Toole et al., 1984; Gitschier et al., 1985a, 1985b; Antonarakis et al., 1985a, 1985b; Wion et al., 1986; Janco et al., 1986; Oberle et al., 1985a; Harper et al., 1984; Tonnesen et al., 1984; Winter et al., 1985).

In this paper we have analyzed restriction fragment length polymorphisms (RFLPs) to detect carriers in 20 Japanese haemophilia A families using an intragenic DNA probe and a factor VIII-linked DNA probe (ST 14-1).

\section{MATERIALS AND METHODS}

Subjects. The 30 normal female and five male subjects analyzed in this study were all selected from Japanese staff members working in our department. Twentytwo patients with haemophilia A were diagnosed in 20 families. Two patients including one female, showed a mild form of haemophilia A with $1-5 \%$ factor VIII coagulant activity (F.VIII:C). The remaining 20 cases had severe forms of haemophilia $\mathrm{A}$ and their F.VIII:C were all less than $1 \%$. Four severe cases showed inhibitor (35-650 Bethesda units $/ \mathrm{ml}$ ). In all cases, the mothers of the male patients were carriers when diagnosed by the bio-immunological assay and pedigree analysis.

Gene probes. The intragenic factor VIII gene probe (F8A) and the extragenic ST 14-1 probe in plasmid vectors (pUC 12 and pBR 322, respectively) amplified in MC $1061 E$. coli were separated by agarose gel electrophoresis, were radio-labeled by nick translation (Rigby et al., 1977), and denatured by heating before hybridization. F8A probe (647 bp, StuI/ScaI fragment) (Gitschier et al, 1985a) covers the exon 17 and 18 and the site of BclI polymorphism (Fig. 1). The ST 14 locus has been mapped in the $\mathrm{Xq} 26-28$ region and is considered to be one of the most polymorphic loci known to date in the human genome. Seventeen different genotypes

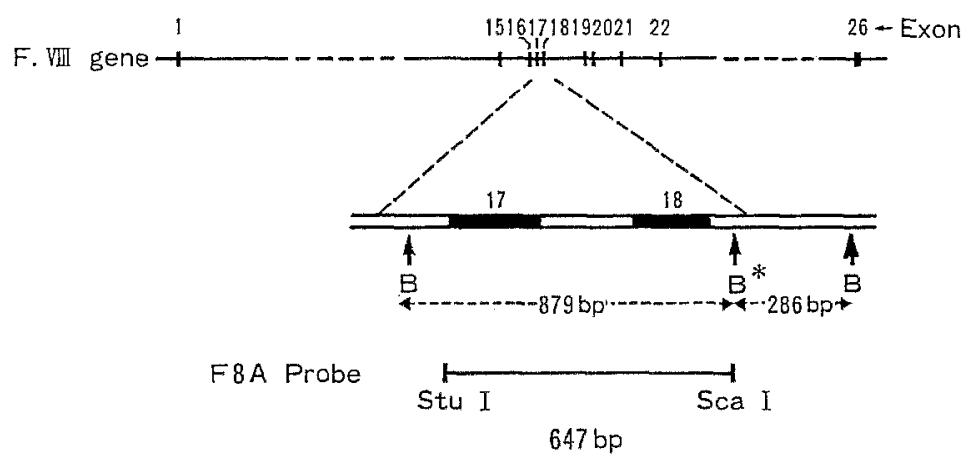

Fig. 1. Position of $B c l$ I polymorphism within factor VIII gene. B*, polymorphic site (Gitschier et al., 1985a). 
have already been observed (Oberle et al., 1985a). The ST 14-1 probe (3.0 kb EcoRI fragment) is one of the ST 14 fragments which reveals at least 8 allelic fragments ranging from $6.6 \mathrm{~kb}$ to $3.4 \mathrm{~kb}$ (Oberle et al., 1985b).

Analysis of restriction fragment length polymorphisms (RFLPS). High molecular genomic DNA was isolated from leukocytes in $20-30 \mathrm{ml}$ of citrated peripheral blood as described previously (Nishino et al, 1986). Ten $\mu \mathrm{g}$ of genomic DNA were digested with two kinds of restriction endonucleases (BclI and TaqI; Toyobo, Japan) under conditions recommended by the supplier. The DNA was then precipitated with ethanol and reconstituted in $100 \mu \mathrm{l}$ of Tris- $\mathrm{HCl}$ buffer, $\mathrm{pH} 8.0(10 \mathrm{~mm}$ Trizma base; Sigma) containing $1 \mathrm{mM}$ EDTA, 7.5\% Ficoll and $0.25 \%$ Bromphenol blue. The DNA samples ( $3 \mu \mathrm{g}$ DNA) were electrophoresed in $0.7 \%$ agarose gel and were blotted onto a nitrocellulose filter (Southern, 1975).

Hybridization was performed with ${ }^{32} \mathrm{P}$-labeled factor VIII probe (F8A) or ST 14-1 probe for $18 \mathrm{hr}$ at $65^{\circ} \mathrm{C}$ in $0.5 \%$ SDS, concentrated 6 times SSC ( $0.15 \mathrm{M}$ sodium chloride and $1.5 \mathrm{~mm}$ sodium citrate), $5 \times$ Denhardt's solution $(0.2 \% \mathrm{w} / \mathrm{v}$ bovine serum albumin, $0.2 \% \mathrm{w} / \mathrm{v}$ polyvinyl-pyrolidone and $0.2 \% \mathrm{w} / \mathrm{v}$ Ficol 400$), 100 \mu \mathrm{g} / \mathrm{ml}$ denatured salmon sperma DNA (Sigma, type III) and $0.01 \mathrm{M}$ EDTA. After hybridization, the excess probe DNA was washed off with $2 \times \mathrm{SSC}$ and $0.1 \% \mathrm{SDS}$ for $20 \mathrm{~min}$ followed by washing $1 \times \mathrm{SSC}$ and $0.1 \% \mathrm{SDS}$ at $65^{\circ} \mathrm{C}$. Then, the DNA fragment were detected by autoradiography with Fuji X-ray film and an intensifying screen.

\section{RESULTS}

\section{BclI polymorphism for factor VIII gene}

Southern blot analysis of $B c /$ I-digested DNA was performed using F8A probe in 35 normal subjects and 20 hacmophilia A families. In normal subjects, the probe revealed two common alleles of $0.9 \mathrm{~kb}$ and $1.2 \mathrm{~kb}$ lengths. Out of 65 normal $\mathrm{X}$ chromosomes (30 female and five male subjects), $56(86 \%$ ) showed the smaller allele $(0.9 \mathrm{~kb})$ and nine $(14 \%)$ showed the larger allele $(1.2 \mathrm{~kb})$. In other words, nine $(30 \%)$ of the normal females showed heterozygosity for $B c l$ polymorphism.

Of 20 mothers of haemophiliacs who were diagnosed as carriers, six mothers were heterozygous for $B c l$ ll polymorphism. Figures 2 and 3 show examples of families in which haemophilia genes can be identified by $B c l$ I alleles. Family A (Fig. 2) consists of a haemophiliac (II-4), his three sisters (II-1, 2 and 3), his mother (I-2) and his father (I-1). The $1.2 \mathrm{~kb}$ allele was related to the gene for haemophilia. Consequently, two band-pattern of $0.9 \mathrm{~kb}$ and $1.2 \mathrm{~kb}$ alleles indicated carrier status for haemophilia $A$. On the other hand, one $0.9 \mathrm{~kb}$ band pattern in the female or male represented the presence of the normal gene. Family B (Fig. 3) consists of a haemophiliac (II-2), his sister (II-1), his mother (I-2) and his father (I-1). The 1.2 $\mathrm{kb}$ allele was used as a marker for the haemophilia gene and the sister with one $0.9 \mathrm{~kb}$ band pattern was determined to have two normal factor VIII genes. 


\section{FAMILY A}

I

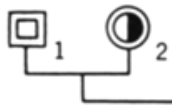

II
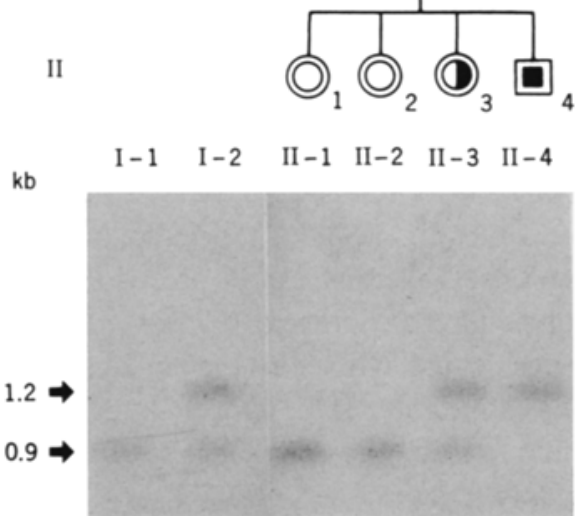

Fig. 2. RFLP pattern of factor VIII gene digested by $B c /$ I in a family with haemophilia A using factor VIII gene probe (F8A).

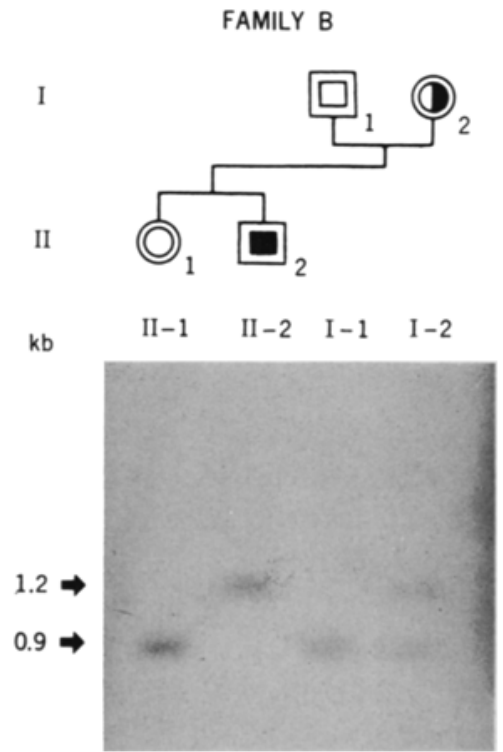

Fig. 3. RFLP pattern of factor VIII gene digested by $B c / I$ in a family with haemophilia $A$ using factor VIII gene probe (F8A).

TaqI polymorphisms for ST 14 locus

In 20 families with haemophilia A, TaqI RFLP for ST 14 was observed. The ST $14-1$ probe revealed eight alleles ranging from $6.6 \mathrm{~kb}$ to $3.1 \mathrm{~kb}(6.6,5.4,4.8,4.4$, 


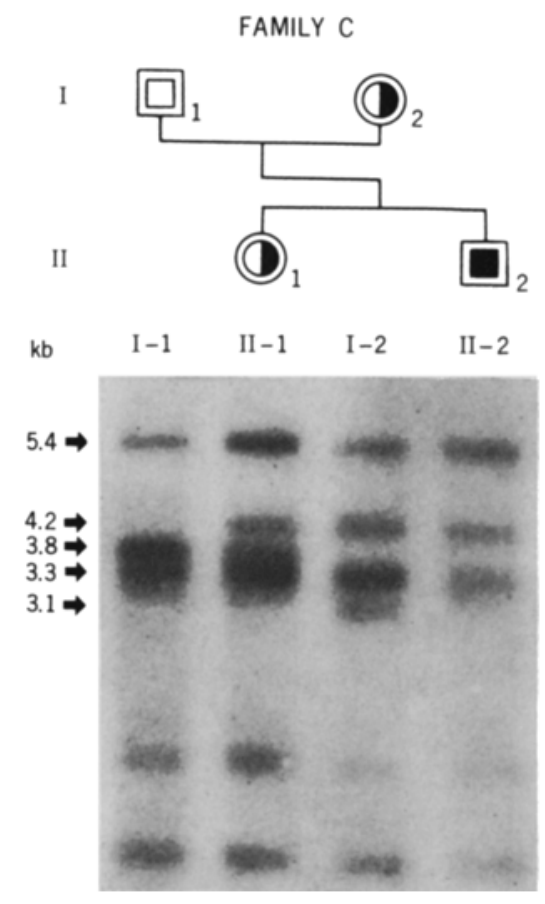

Fig. 4. RFLP pattern of ST 14 locus digested by TaqI in a family with haemophilia A using ST 14-1 probe.

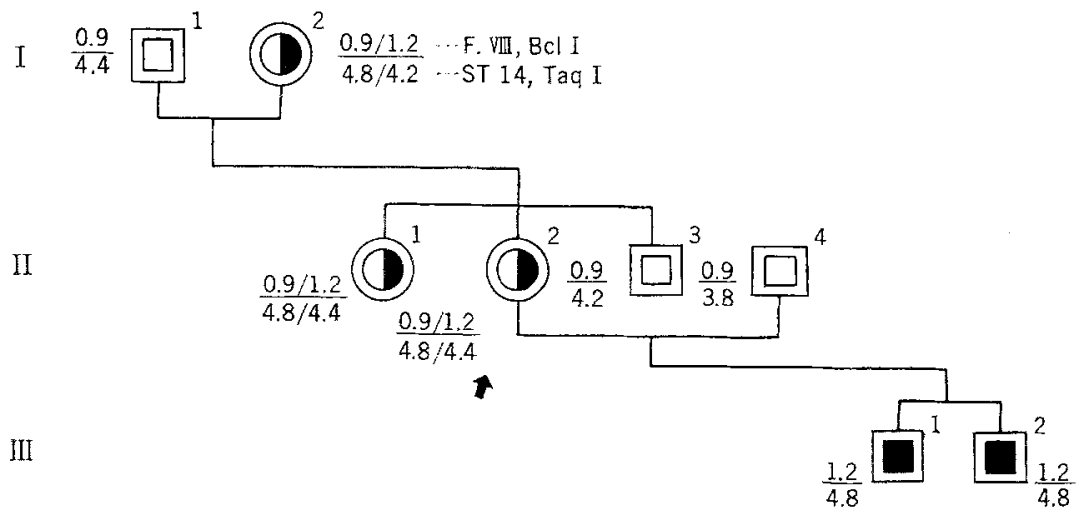

Fig. 5. Genotypes of factor VIIl gene and ST 14 locus in a female haemophilia A family revealed by the use of F8A probe and ST 14-1 probe.

$4.2,3.8,3.3$ and $3.1 \mathrm{~kb}$ ). However, the $6.6 \mathrm{~kb}$ allele was identified in only one case out of 120 chromosomes. In 11 of the 20 haemophilic families, the TaqI polymorphisms for the ST 14 locus were indicative of the carrier state. Family C (Fig. 4) showed the $4.2 \mathrm{~kb}$ allele which was identified as a marker for the haemophilia gene 
since this allele was found in the propositus and his mother but not in his father. On the other hand, the $3.1 \mathrm{~kb}$ allele was considered to be derived from the normal $\mathrm{X}$-gene of the mother. The daughter in Family $\mathrm{C}$ showed the $4.2 \mathrm{~kb}$ allele but not the $3.1 \mathrm{~kb}$ allele. Thus, she was diagnosed as a carrier.

\section{A female haemophilia A family observed by F8A and ST 14-I probes}

The female proposita (II-2) reported previously (Yoshiya et al., 1969) had a mild type of haemophilia A with 3\% F.VIII:C. As shown in Fig. 5, two sons (III1 and 2) had severe haemophilia $\mathrm{A}$ and showed the $1.2 \mathrm{~kb}$ allele (F8A, $B c l$ I digestion) and the $4.8 \mathrm{~kb}$ allele (ST 14-1, TaqI digestion). Both were identified as the haemophilia gene. Her father, (I-1) who did not have a coagulation disorder, showed the $0.9 \mathrm{~kb}$ allele (F8A) and the $4.4 \mathrm{~kb}$ allele (ST 14-1), and her normal brother (II-3) showed the $0.9 \mathrm{~kb}$ allele (F8A) and the $4.2 \mathrm{~kb}$ allele (ST 14-1). From these results, it was concluded that the female propositus (II-2), her sister (II-1) with $0.9 / 1.2 \mathrm{~kb}$ (F8A) and 4.8/4.4 kb (ST 14-1) alleles, and her mother (I-2) with 0.9/1.2 kb (F8A) and 4.8/4.2 kb (ST 14-1) alleles were carriers of haemophilia A.

\section{DISCUSSION}

Recently, RFLPs have been used for both the prenatal diagnosis and carrier detection in a number of genetic diseases such as phenylketonuria and Lesch-Nyhan syndrome. In haemophilia A, Gitschier et al. (1985a) observed a Bcll polymorphic site in the intron 18 of factor VIII gene after examining polymorphisms for 37 restriction endonuclease using a full length cDNA probe. Subsequently, Wion et al. (1986) discovered another polymorphic site of $X b a \mathrm{I}$ in the intron 22 and Tuddenham et al. (1986) have examined a new BglI polymorphic site in the intron 25 . The frequency of RFLP in the factor IX gene in Japanese haemophilia B families was significantly less than in Caucacian people (Mikami et al., 1987). In order to reveal whether RFLP in the factor VIII gene reported in Caucasians is present in Japanese, we analyzed the $B c l$ I RFLP of factor VIII genes in Japanese. When DNA from 30 normal females and five normal males was examined for $B c l$ I polymorphism in the factor VIII gene, it was found that the frequency of the two alleles was $86 \%$ for the $0.9 \mathrm{~kb}$ allele and $14 \%$ for the $1.2 \mathrm{~kb}$ allele and the frequency of heterozygous females recognized by the F8A marker was $30 \%(9 / 30)$. Therefore, it was suggested that the $B c l I$ polymorphism in the factor VIII gene was useful for analyzing haemophilia $A$ gene in Japanese families. Indeed, of the 20 Japanese families with haemophilia A studied, we have identified the relationship between $B c /$ I alleles and haemophilia genes in six families $(30 \%)$ (Table 1). However, it may also suggest that the frequency of heterozygous females for BclI polymorphism was less in Japanese than in Caucasian people $(42 \%$, Gitschier et al., 1985a). We presume that there are also some differences of polymorphisms in factor VIII genes among human races as we previously reported in factor IX genes (Mikami et al., 1987). 
Table 1. Frequency of $\mathrm{Bcl}$ polymorphism in factor VIII gene in 35 unrelated normal subjects and 20 unrelated haemophilia $A$ carriers.

\begin{tabular}{llccccc}
\hline & & Normal & \multicolumn{2}{c}{ Hemophilia carriers } \\
\hline Examined number & female & male & & 30 & & 20 \\
& & 5 & & & 0 \\
\hline Number of X-chromosome with & B1 & B2 & Total & B1 & B2 & Total \\
each alleles & 56 & 9 & 65 & 32 & 8 & 40 \\
\hline Frequency & 0.86 & 0.14 & & 0.80 & 0.20 \\
\hline Frequency of heterozygote in female & & $9 / 30(0.30)$ & & $6 / 20(0.30)$ \\
\hline
\end{tabular}

B1 allele, $0.9 \mathrm{~kb}$ fragment; B2 allele, $1.2 \mathrm{~kb}$ fragment.

Table 2. Frequency of alleles for intragenic and linked RFLPs in haemophilia A carriers.

\begin{tabular}{|c|c|c|c|c|}
\hline Probe & Enzyme & $\begin{array}{l}\text { Alleles } \\
(\mathrm{kb})\end{array}$ & $\begin{array}{l}\text { Frequency } \\
\qquad \%)\end{array}$ & $\begin{array}{c}\text { Heterozygosity } \\
(\%)\end{array}$ \\
\hline Factor VIJI exon 17.18 (F8A) & $B c / I$ & $1.2 / 0.9$ & $80 / 20$ & 30 \\
\hline ST 14-1 & TaqI & at east 7 & $\ldots$ & 55 \\
\hline $\mathrm{F} 8 \mathrm{~A}+\mathrm{ST} 14-1$ & $\begin{array}{l}B c l \mathrm{I} \\
\operatorname{Taq} \mathbf{I}\end{array}$ & $\cdots \cdots$ & $\ldots \ldots$ & 70 \\
\hline
\end{tabular}

The linkage map for the human $\mathrm{X}$ chromosome has been constructed. Some RFLP markers which could incorporate with the loci corresponding to genetic diseases have been used for researches on sex-linked recessive diseases such as Duchenne muscular dystrophy and fragile X chromosome syndrome. Oberle et al. (1985a) reported a new polymorphic probe named ST 14 that has been mapped to the Xq2628 region. The relative order of the genetic marker loci in X27-qter region is most likely "cen-. . 52A-FIX-ST14,DX13" (Drayna et al., 1984) or "cen-. . .FIXFVIII--DX13,ST14-Xqter" (Tantrabahi et al., 1986). It has been reported that the lod score for the linkage of factor VIII to ST 14 is 19.0 and the recombination unit between them is less than 4.6. The probe ST 14 detects a polymorphic system defined by a series of at least eight allelic fragments with a calculated heterozygosity of $80 \%$ in females when digested with TaqI. In 11 Japanese haemophilia A families out of 20 studied, ST 14-1 probe and TaqI polymorphisms were useful for carrier detection.

The combined heterozygosity of females for both F8A and ST 14 polymorphism was reported to be $100 \%$ by Janco et al. (1986). On the other hand, meiotic recombination has been reported between factor VIII gene and ST 14 with $4.5 \%$ accuracy (Driscoll et al., 1986; Lehesjoki et al., 1986). In our study, three families detected by both probes suggested that recombination had not occurred. In our 20 families, the combined heterozygosity of females was $70 \%$ using both F8A and ST $14-1$ probes 
and in 14 families carriers were detected (Table 2). For more precise information on the detection of carriers in Japanese families, studies using more RFLP markers such as $X b a I$ and $B g l I$ polymorphisms will be required.

Acknowledgments We wish to thank Dr. R.M. Lawn in Genentech, Inc., Calfornia for providing the F8A probe and Prof. P. Chambon in Faculte de Medicine (Strasbourg, France) for providing gene probe ST 14-1.

\section{REFERENCES}

Antonarakis, S.E., Copeland, K.L., Carpenter, R.J., Carta, C.A., Hoyer, L.W., Caskey, C.T., Toole, J.J., and Kazazian, H.H., Jr. 1985a. Prenatal diagnosis of haemophilia A by factor VIII gene analysis. Lancet I: 1407-1409.

Antonarakis, S.E., Warber, P.G., Smita, M.S., Kittur, D., Patel, A.S., Kazazian, H.H., Jr., Mellis, M.A., Counts, R.B., Stamatoyannopoulos, G., Bowie, E.J.W., Fass, D.N., Pitman, D.D., Woozney, J.M., and Toole, J.J. 1985b. Hemophilia A: Detection of molecular defects and carriers by DNA analysis. N. Engl. J. Med. 313: 842-848.

Drayna, D., Davie, K., Hartley, D., Mandel, J.-L., Camerino, G., Williamson, R., and White, R. 1984. Genetic mapping of human $X$ chromosome by using restriction frament length polymorphisms. Proc. Natl. Acad. Sci. U.S.A. 81: 2836-2839.

Driscoll, M.C., Miller, C.H., Goldberg, J.D., Aledort, L.M., Hoyer, L.W., and Golbus, M.S. 1986. Recombination between factor VIII:C gene and ST 14 locus. Lancet II: 279.

Gitschier, J., Wood, W.I., Goralka, T.M., Wion, K.L., Chen, E.Y., Eaton, D.H., Vehar, G.A., Capon, D.J., and Lawn, R.M. 1984. Characterization of the human factor VIII gene. Nature 312: $326-330$.

Gitschier, J., Drayna, D., Tuddenham, E.G.D., White, R.L., and Lawn, R.M. 1985a. Genetic mapping and diagnosis of hemophilia $A$ achieved through a $B c / I$ polymorphism in the factor VIII gene. Nature 314: 738-740.

Gitschier, J., Lawn, R.M., Rotblat, F., Goldman, E., and Tuddenham, E.G.D. 1985b. Antenatal diagnosis and carrier detection of haemophilia A using factor VIII gene probe. Lancet $\mathbf{I}$ : 1093-1094.

Graham, J.B., Rizza, C.R., Chediak, J., Mannucci, P.M., Briet, E., Ljung, R., Kasper, C.K., Essien, E.M., and Green, P.P. 1986. Carrier detection in hemophilia A: A cooperative international study. I. The carrier phenotype. Blood 67: 1554-1559.

Green, P.P., Mannucci, P.M., Briet, E., Ljung, R., Kasper, C.K., Essien, E.M., Chediak, J., Rizza, C.R., and Graham, J.B. 1986. Carrier detection in hemophilia A: A cooperative study. II. The efficasy of a universal discriminant. Blood 67: 1560-1567.

Harper, K., Winter, R.M., Pembrey, M.A., Hartley, D., Davies, K.E., and Tuddenham, E.G.D. 1984. A clinically useful DNA probe closely linked to haemophilia A. Lancet II: 6-8.

Janco, R.L., Philips J.A., III, Orlando, P., Davies, K.E., Old, J., and Antonarakis, S.E. 1986. Carrier testing strategy in haemophilia A. Lancet I: 148-149.

Lehesjoki, A.-E., Chapelle, A., and Rasi, V. 1986. Hemophilia A: Two recombinations detected with probe ST 14. Lancet II: 280.

Mikami, S., Nishino, M., Nishimura, T, and Fukui, H. 1987. RFLPs of factor IX gene in Japanese haemophilia B families and gene deletion in two high-responder-inhibitor patients. Jpn. J. Human Genet. 32: 21-31.

Nishino, M., Nishimura, T., Naka, H., Nakai, H., Miyata, S., Oku, K., and Mikami, S. 1986. Southern blot analysis of factor IX gene in hemophilia B. J. Nara Med. Assoc. 37: 762-768.

Oberle, I., Camerino, G., Heilig, R., Grunebaum, L., Cazenave, J.P., Crapanzano, C., Mannucci, 
P.M., and Mandel, J.L. 1985a. Genetic screening for hemophilia A (classical hemophilia) with a polymorphic DNA probe. N. Engl. J. Med. 312: 682-686.

Oberle, I., Drayna, D., Camerino, G., White, R., and Mandel, J.L. 1985b. The telomeric region of the human $\mathrm{X}$ chromosome long arm: Presence of a highly polymorphic DNA marker and analysis of recombination frequency. Proc. Natl. Acad. Sci. U.S.A. 82: 2824-2828.

Rigby, P.W.J., Dieckmann, M., Rhodes, C., and Berg, P. 1977 . Labeling deoxyribonucleic acid to high specific activity in vitro by nick translation with polymerase I. J. Mol. Biol. 113: 237-251.

Southern, E.M. 1975. Detection of specific sequences among DNA fragments separated by gel electrophoresis. J. Mol. Biol. 98: 503-517.

Tantrabahi, U., Murty, V.V.V.S., Jhanwar, S.C., Toole, J.J., Woozney, J.M., Chaganti, R.S.K., and Latt, S.A. 1986. Physical mapping of the factor VIII gene proximal to two polymorphic DNA probes in human chromosome band Xq28: Implications for factor VIII gene segregation analysis. Cytogenet. Cell Genet. 42: 75-79.

Tonnesen, T., Sondergaard, F., Mikkelsen, M., Davies, K.E., Old, J., Winter, R.M., and Hauge, M. 1984. X-chromosome-specific probe DX 13 for carrier detection and first trimester prenatal diagnosis in haemophilia A. Lancet II 1269-1270.

Toole, J.J., Knopf, J.L., Wozney, J.M., Sulzman, L.A., Buocker, J.L., Pittman, D.D., Kaufman, R.J., Brown, E., Shoemaker, C., Orr, E.C., Amphlet, G.W., Foster, W.B., Coe, M.L., Knutson, G.J., Fass, D.N., and Hewick, R.M. 1984. Molecular cloning of cDNA encoding human antihemophilic factor. Nature 312: 342-347.

Tuddenham, E.G.D., Wion, K., and Lawn, R. 1986. Restriction fragment length polymorphisms linked to factor VIII. Proc. 5th Int. Symp. H.T., Tokyo, pp. 43-53.

Winter, R.M., Harper, K., Goldman, E., Mibashan, R.S., Warren, R.C., Rodeck, C.H., Penketh, R.J.A., Ward, R.H.T., Hardisty, R.M., and Pembrey, M.E. 1985. First trimester prenatal diagnosis and carrier detection of haemophilia A using the linked DNA probe DX 13. $B r$. Med. J. 291: 765-769.

Wion, K.L., Tuddenham, E.G.D., and Lawn, R.M. 1986. A new polymorphism in the factor VIII gene for prenatal diagnosis of hemophilia A. Nucleic Acids Res. 14: 4535-4542.

Yoshiya, H., Kamisue, M., Adachi, T., and Fukui, H. 1969. Hemophilia A in a woman with female sex-chromosome. J. Nara Med. Assoc. 20: 559-567. 